Article

\title{
160 Years of Borders Evolution in Dunkirk: Petroleum, Permeability, and Porosity
}

\author{
Stephan Hauser ${ }^{1}$, Penglin Zhu ${ }^{1, *}$ and Asma Mehan ${ }^{2}$ \\ ${ }^{1}$ Faculty of Architecture and the Built Environment, Delft University of Technology, The Netherlands; \\ E-Mails: s.j.hauser@tudelft.nl (S.H.), p.zhu@tudelft.nl (P.Z.) \\ ${ }^{2}$ Faculty of Social and Behavioural Sciences, Leiden University, The Netherlands; E-Mail: a.mehan@fsw.leidenuniv.nl \\ * Corresponding author
}

Submitted: 30 January 2021 | Accepted: 8 May 2021 | Published: 27 July 2021

\begin{abstract}
Since the 1860s, petroleum companies, through their influence on local governments, port authorities, international actors and the general public gradually became more dominant in shaping the urban form of ports and cities. Under their development and pressure, the relationships between industrial and urban areas in port cities hosting oil facilities evolved in time. The borders limiting industrial and housing territories have continuously changed with industrial places moving progressively away from urban areas. Such a changing dynamic influenced the permeability of these borders. Port cities are nodes and logistic points where various flows of commodities, wealth, and knowledge gathered before further re-distribution. These flows affected port cities by changing their spatial organization and the availability of space between borders. The main question here is: How did industrial and urban borders evolve through time in port cities? Through a historical analysis, the article explores the settlements of oil facilities and the influence of oil companies over local, regional, and national governments in creating borders and how it influenced the porosity of port cities. This article, through the petroleum narrative, illustrates the impacts of past borders on the contemporary urban form through the evolution of the French port city of Dunkirk, in the North of France. As a historical study, the article analyzes the changing relationships between petroleum industrial sites and housing areas in the city of Dunkirk, using aerial pictures, archival sources, and regulations of different periods. The importance of this analysis lies in knowing that former oil sites previously located on the periphery of Dunkirk, that were forgotten by the authorities are now located within the current urban tissue. This process demonstrates the importance of historical developments to understand current challenges in the urban planning of industrial port cities.
\end{abstract}

\section{Keywords}

borders; Dunkirk; energy transition; oil industry; port cities; urban history

\section{Issue}

This article is part of the issue "Planning for Porosity: Exploring Port City Development through the Lens of Boundaries and Flows" edited by Carola Hein (Delft University of Technology, The Netherlands).

(C) 2021 by the authors; licensee Cogitatio (Lisbon, Portugal). This article is licensed under a Creative Commons Attribution 4.0 International License (CC BY).

\section{Introduction}

For more than a decade, scholars have linked 'porous,' a term usually used in biology, with the concept of the border to describe all sorts of dynamics between the different urban elements of a city. Richard Sennett (2010), a leading American-based sociologist, compares the neigh- borhoods in a city with cells since both are resistant as well as permeable. He implies that borders are dangerous areas of interactions, serving as tense, combative zones rather than friendly sites of exchange. In 2015, Sennett elaborated on the concept of porous cities using Nehru Place, an open-air electronic market in Delhi, as an example to advocate nurturing the complexity of the 
identity to make more room for diversity. Sennett (2015) describes the place not only as a true mixed use of public and private functions such as schools and clinics, but also as one which includes people coming from different nations and having various religious beliefs.

The creation of permeable borders by different oilrelated actors captures the dialectic relations of separation and inclusion taking place. It also shows how the history of flows and actors, particularly linked to petroleum activities, has influenced port city's borders. Intertwined inextricably with global capital, the success of the petroleum economy depended on its continuous expansion (Szeman, 2007), which stimulated urban growth and fostered the demise and birth of borders in port cities. Where oil companies carry out oil trade and activities, environmental risks threaten cities and citizens (Hein, 2011, 2018). Since the mid-19th century, port cities worldwide have evolved together with the development of this oil industry (Tarigan et al., 2017).

To investigate how borders between industrial oil sites and urban areas evolved through time in port cities, one of the main obstacles is the precise use of terms. In the perspective of this article, precision is a challenge considering the debates around the many notions discussed. As such, it seemed particularly important to place the argument within a clear frame before illustrating the spatial importance of these changing borders in Dunkirk, a port city on the North coast of France. The particularities of the oil narrative in this port city make it a representative example to demonstrate the role of history and urban planning in identifying the permeability of borders. The article then discusses the implications of such changing interactions between oil sites, ports, and urban areas in Dunkirk. These changes are then linked to recent concerns regarding security around industrial ports and the ongoing challenges related to the energy transition and the environment. Former industrial areas with their polluting activities and formerly on the periphery are, now, in port cities' urban areas. They have become threats for the security and health of citizens and a challenge for the public authorities managing the spatial organization of industrial port cities. This exemplifies the importance of investigating the evolution of cities' porosity and borders' permeability when discussing petroleum industrial settlements and the health of citizens in port cities.

\section{The Use of Terms}

\subsection{An Understanding of Borders and Porosity in Port Cities}

The definition of port cities has always been challenging and changing through time because of their complexity (Ducruet, 2007). The role and significance of port cities tend to be particularly sensitive to changes arising from larger contextual political, economic, and technical transformations unfolding around them, as well as endogenously-initiated changes to their own built environment. It means that any serious analysis of port cities must therefore necessarily take an integrated approach to the complex interactions between a port city's-built environment, metropolitan spatial form, urban planning actors, and economic and commercial land and sea networks (Hein, 2011, p. 285).

The port and the city have long influenced each other (Hall \& Jacobs, 2012; Monios et al., 2018). The economic activity of a port city depends on the competitiveness of its port, while port and industrial actors often consider urban areas as an obstacle to the development of their activities (Ducruet, 2007). This dependency also goes together with a form of competition for space, with port authorities fearing urban policies hindering their development, while cities' authorities fear an increase in adverse environmental impacts linked to the growth of port activities (Ažman Momirski, 2015). Because of such a complexity, port and city can no longer be analyzed independently, especially when talking about their economic and spatial developments, and their effects on the surrounding environments and citizens.

The notion of 'borders' in port cities is here understood as the physical and administrative delimitations between industrial and urban activities. On the one hand, the definition of port cities implies that port activities were, at first, located around, if not within the urban fabric of industrial port cities. On the other hand, the explanation of oil through its actors and activities, their importance, scales, and consequences, gives a hint on the threat that they represent for citizens' health and security, as well as on the quality of the surrounding environment. Under such a threat for inhabitants, borders evolved into a powerful tool protecting them against dangerous sites. The infrastructure often played this role, with railways, highways or pipelines creating the physical borders, cutting through cities and dividing them.

Borders are central to the definition of urban districts and industrial areas. In port cities, the changing permeability of borders through times, between industrial sites and housing districts, is another crucial aspect to consider. The influences and effects of borders are not bounded by legal or geographic considerations only. Water and pollution do not stop at borders, natural or human ones. On land or at sea, industrial activities affect citizens, animals, the air, the water, and the soil. This process means that instead of considering borders as a simple two-dimensional line, one needs to understand its three-dimensional implications. This conceptualization is a key element, especially when discussing the contemporary spatial planning of industrial port cities as it affects inhabitants for a long period.

Since the beginning of petroleum developments in the 1860s, entrepreneurs thrived on the territory of port cities like Dunkirk, building numerous storage and transformation sites for the oil coming from the hinterland and beyond. Most of them were located either at the periphery or sometimes within the city. With the growth 
of the port-city, parcels hosting the sites formerly located outside the city are now part of the urban tissue. Land uses changed in time, passing from the industrial sites to, in most cases, residential areas, without much concern for the quality of the soil and the future use of the land. Public and private authorities mostly ignored the pollution and its potential effects on health and the environment before the international rise of the environmental concern in the 1970s (Brimblecombe, 1999; Mosley, 2014), while even silencing public debates around the question (Le Roux, 2015).

Jovchelovitch et al. (2020) have already exemplified the current challenges around the definition and explanation of borders and porosity in urban environments. Borders can be both tangible, with concrete walls dividing spaces and restricting movements, and intangible, through cultural or historical processes meant to segregate and configure a territory. These lines can also have dual implications as they can be areas of contact or conflict, gateways or barriers, limiting and allowing exchanges. Jovchelovitch et al. (2020) exemplified through their argument the inherent and multiple porosities of these borders, as well as the extensive factors that can intervene in their definition.

\subsection{The Importance of Port Cities, Oil, Borders, and Porosities: The Case of Dunkirk}

The port city of Dunkirk is located on the north coast of France, near the Belgian border, and in front of the United Kingdom. In the 1860s, when the oil business started, many investors saw potential in the resource and settled new installations in the French port city. While the area represented an advantageous location for oil actors with connections to both the hinterland and the rest of the world, public authorities considered this new activity an economic opportunity for the development of the port city. Relying on the political support of local and national decision-makers, oil actors participated in the growth of port cities but also shaped them according to their needs for land and workers.

The case of Dunkirk is an excellent illustration of the complexity mentioned above. The relationship between petroleum sites and urban areas in this port city began in the early stages of the oil industry's development. Jean-Baptiste Trystram, for instance, built the first refinery of Dunkirk in 1861 on what was, at the time, the South-West periphery of the port city. Many other sites emerged following the example set by Trystram. Many settled on the periphery of the city before being progressively included in the urban tissue, developing different borders within the city, and different permeabilities, affecting cities' porosity and their consequences on citizens. Regular incidents, combined with a growing need for industrial sites for space, led to creating a port area now 15 kilometers long in Dunkirk. This separate spatial entity, industrial needs, infrastructural, environmental, health, and security rules influenced another understanding of the relation between industrial sites and the city. Nevertheless, past and current practices linked, in the present case, to the spatial definition of borders around oil sites affected and still impact citizens and the efficiency of planning policies in industrial port cities like Dunkirk (Hein, 2018; Hein et al., 2020, 2021; Hein \& van de Laar, 2020).

The long oil history of Dunkirk is progressively coming to an end with oil companies closing their refineries in the port and their facilities being transformed and disappearing. Yet, the story of its borders, their permeability and influence on the port city's porosity, as well as their polluting consequences, remain and are transferable to many other places. All the different authorities of port cities in the world experienced similar developments of industries like the oil industry, with first settlements in city centers before moving to detached and dedicated places in ports. It is important to comprehend and analyze this oil history to understand the place and characteristics of borders in port cities, together with the influence of past developments on current urban developments to better plan the future of port cities.

\section{Research Question and Methodology}

Based on the control that oil companies developed to support the creation of their landscape of influence (Hein, 2018), this article studies the evolution of the oil industry with its various spatial and historical developments and impacts on port cities. Taking Dunkirk as an example, it explores how the incidents around the facilities transforming or storing oil and disasters linked to its transportation influenced the evolution of its borders' permeability. These events led to new investments in planning and security around the industrial areas of port cities hosting them. Such improvements are still visible in contemporary shapes of port cities. The article highlights the link between fires related to oil, economic improvements, and new planning practices aiming at a safer environment for citizens in the French port city through archival study. The article especially explores the settlements of oil sites and the influence of oil actors by asking: How have oil companies influenced the definition of interfaces between the port and urban areas at different times?

A careful identification and analysis of urban developments from different sources will allow a better understanding of the history of spatial planning in port cities linked to oil activities. This analysis aims to highlight the evolution of port cities' borders through the lens of oil activities and demonstrate the importance of past developments on the current and future planning of port cities. The recent scholarship has proved that through the use of historical archives, mainly maps, planning documents, and writings, it is possible to locate former and lost industrial sites in the current shape of port cities and identify the incompatibilities in land uses and changing borders (Hauser, 2020). Recognizing the multiplicity of actors and 
factors intervening in the evolution of the oil industry also helps to understand the role of this industry in historical transformations, spatial transformations, and contemporary shapes and challenges of port cities.

The results of this historical research are not applicable to European regions alone, but also transferable to other port cities where the oil industry had and still has a dominant place in the region's economic growth and urban development. Visualizing former oil sites in port cities with the help of historical archives is of primary importance to observe the evolution of borders and efficiently plan for the future use of these polluted sites. The study of maps and aerial pictures confirms the influence of oil industries on the permeability of borders and their consequences on the porosity of the city as they illustrate an absence of enforcement of regulations meant to improve the security of industrial sites for citizens. The creation of maps transcribing these evolutions also allows a better analysis and observation of the historical changes of borders and porosities, and their impact on contemporary shapes of port cities.
To analyze the influence of oil developments, the article uses online archives to support the argument, consisting of aerial pictures, historical reports, literature, archives, policies, and planning documents. Past and contemporary aerial pictures provided by the National institute of Geographic and Forest Information (IGN) help to illustrate the relationship between industrial sites, urban and port areas, and the priority long given to economic interests by public and private authorities in defining borders. Old pictures of Dunkirk are available on the service Remonter le temps (literally meaning 'go back in time') of the IGN, however it is limited to specific areas and dates, and starts in 1920 in the case of Dunkirk. Planning rules and policies but also archival maps and documents testify the pressures on public authorities and the growing control of oil actors over the decision-making process. Table 1 sums up the diversity of materials used to uncover past oil influences and their consequences over the definition of borders, and the influence of the porosity over citizens. The cross-analysis of all these resources allows for a better understanding of past developments

Table 1. A summary of the different materials used in this article.

\begin{tabular}{llll}
\hline Source & Type & Description & Characteristics \\
\hline Regulations and & Legal texts & Rules affecting industrial activities, & Many different types were \\
policies & & $\begin{array}{l}\text { urban planning, health, and } \\
\text { security }\end{array}$ & $\begin{array}{l}\text { considered, ranging from } \\
\text { authorizations to decrees, laws, } \\
\text { among others }\end{array}$
\end{tabular}

Archives of the region and the Learning Center of Dunkirk

Literature on the development of industries and environmentalism

ArcGIS Software

IGN

Online database

Reports

Reports of institutions or governments literature
Archival documents and pictures/plans

Online and offline

ArcGIS is the software used to overlap old maps and pictures on the actual shape of Dunkirk

Online service to visualize maps of France. Through Remonter le temps, it gives access to past and present aerial pictures

Documents assessing the application of laws or the effects of policies
Many types of documents available but not necessarily online. Sometimes the description of the file in the database does not detail the content of the folder

Online articles and books give precious information on the industry of the North of France

The overlapping of historical maps and pictures on the actual and precise plan of the city highlight the evolution of borders in Dunkirk

Excellent quality of images in many places around France. Historical pictures of Dunkirk start in 1920 and are sometimes limited to specific areas

Reports can provide quantitative data on the effects of regulations while making a comparison to other areas 
and the evolution of industrial pressures as well as contemporary challenges and complexity when planning for port cities.

\section{The Narrative of Oil Borders and Their Spatial Consequences}

\subsection{The Early Investments and the Effects of Oil in Dunkirk}

The oil venture started early in Dunkirk in 1861 with the above-mentioned Trystram's refinery. But the establishment of numerous oil sites in Dunkirk went together with rising concerns of public and private actors around the risks their activities brought around the port and urban areas. Fires related to the transport and transshipment of oil in Jersey and Antwerp in 1866 supported the fears around the new industry, as trans-shipment areas were in the city center and early oil sites surrounded by houses and residential districts. Actors of the port city (local authorities, citizens, and business owners) regularly addressed their concerns over the risks of this resource and its storage to the Chamber of Commerce, already pushing for more control over its trade and handling and for a more apparent separation between industries and urban areas.

By demonstrating the effects of a lack of borders on the water, the consistent fires in various ports exemplified the danger of oil activities. It is only after the authorities of the port cities of Bordeaux in 1867 and 1869 and of Dunkirk in 1868 experienced these similar transshipment issues that new management policies emerged.
But these fires had dire and direct consequences on ports, cities, citizens, and economies. Multiple ships burnt, traumatizing the population and influencing the future shape of ports as well as their management. Among other reactions of the public authorities, new dedicated places and tools for petroleum trade appeared in Dunkirk. The transshipment docks for oil moved outside the port city centers. This new planning of ports created the first physical distinction between the city and the port.

The new port and its borders progressively led local inhabitants to lose their close relationship with the port. Industrial owners progressively settled their facilities in these areas to benefit from port facilities. Through consecutive transformations, the port of Dunkirk evolved to become one of the most important ports in France, the Freycinet Plan; the name of the public works minister Charles Freycinet triggered a first evolution in 1878 (Figure 1). The aim was not only to improve the port of Dunkirk, but the entire French port infrastructure, with new railways and canals connecting to the hinterland (Gonjo, 1972). The search for economic efficiency drove this first division of ports and cities while indirectly participating in the improvement of citizens' security against explosions and fires through the definition of a strict border represented by the distance between port activities and urban areas.

The improvements in the relation between urban planning of port-cities and the settlements of industrial sites kept, however, on being linked to dreadful events. Public and private authorities did not immediately move industrial sites storing and transforming oil

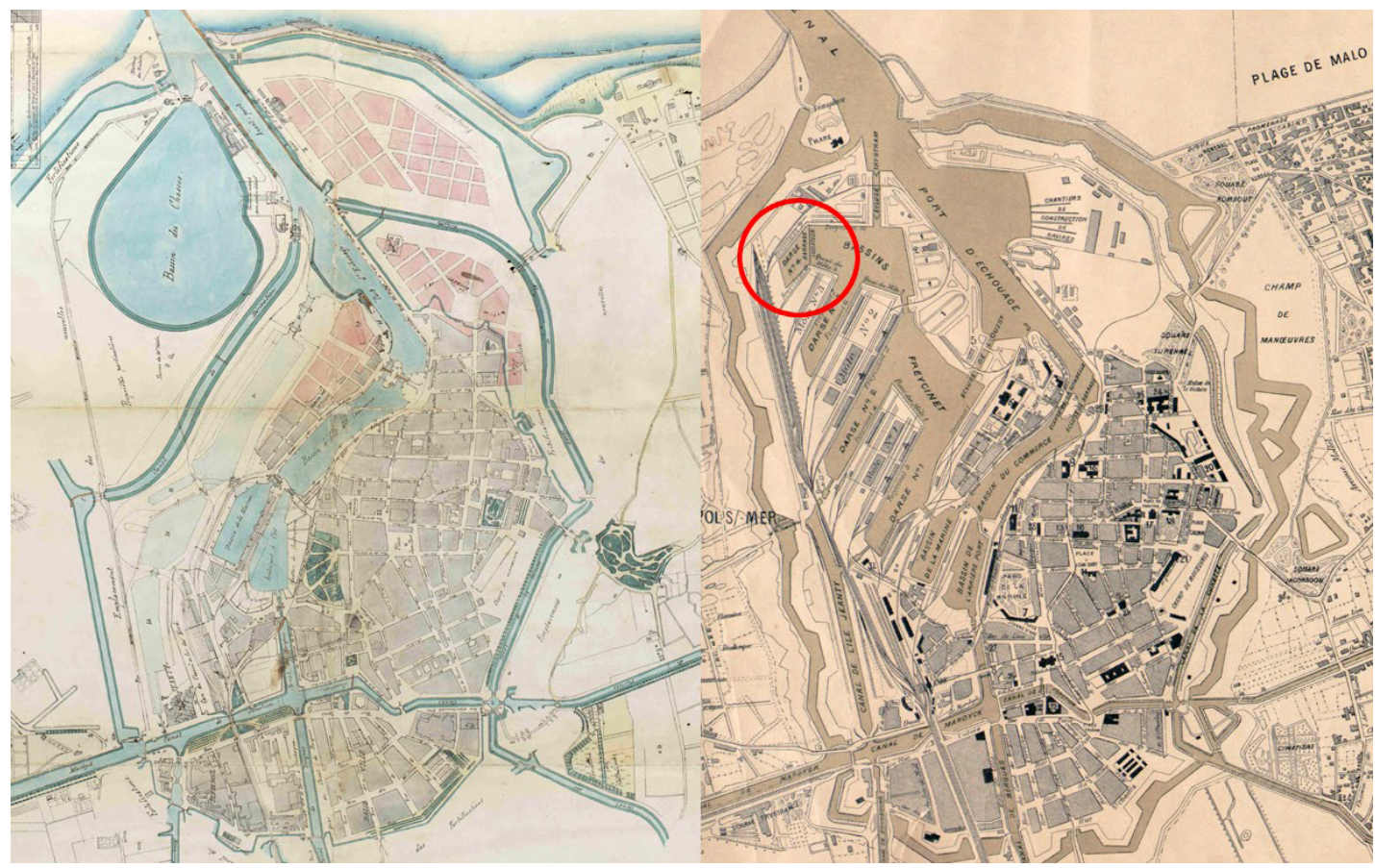

Figure 1. Maps of the port city of Dunkirk. On the left, Dunkirk in 1875, and on the right in 1910 after the modifications of the Freycinet Plan. The red circle highlights the location of the floating dam and the basin dedicated to oil, the furthest away from the city center. Source: Centre de la Mémoire Urbaine d'Agglomération (n.d.-a, n.d.-b). 
into the port's territory. Oil facilities kept on settling nearby if not next to living spaces. The fire and explosion of the refinery Clère-Boilet in Coudekerque-Branche in 1891 (part of contemporary Dunkirk) highlighted, among others, the remnants of the tight and dangerous relationship that the urban fabric had with industrial sites.

The division of spaces between industrial and urban lands promoted by the Freycinet Plan for economic efficiency did not impact the already settled and longstanding oil sites in the city. In 1891, a terrible explosion in the facility followed by a great fire destroyed the site. It spread, burning oil for 500 meters, killed seven people, and destroyed numerous houses located around the facility (Denise, 1988). Inhabitants of the city alerted local authorities again to the danger of this petroleum site and its location within the urban tissue after multiple other fires broke out in this same facility. Yet this incident did not prevent the refinery from being rebuilt in the same place before eventually closing a few years later. Before the first World War, private actors, with the support of public authorities, settled multiple oil facilities nearby houses in Dunkirk, without any considerations for the risks that such activities could have on human lives, health, and the environment. The regular and previous incidents linked to oil storage, transformation, or transportation triggered a reaction from public authorities, with new designs (port areas) and planning rules (distance between industrial sites and houses), but public authorities rarely enforced them or monitored their application.

The long-standing practice of settling facilities near residential areas or sometimes right next to them represented the powerful ties between public and private actors, as well as the danger of porous borders around industrial sites. Considerations for the security and health of workers and citizens were an obstacle in the way of industrial developments and constraining rules for investors. Citizens were also benefiting from this practice. It was convenient both for employees and employers to have this permeability so long as nothing happened. The case of the refinery Clère-Boilet illustrated this problem when a deadly incident occurred. With the following settlements of similar facilities, the competent administration for the authorization required new equipment and planning rules. They became visible in prefectural documents through the authorizations given to industry to settle. These documents created new conditions linked to the settlement of industrial facilities with a two meters high wall around the facility and paved basins for storage units. These new requirements participated in the production of stricter borders between industrial sites and the rest of the city, though these sites remained within the city. This creation transformed borders which became a tool to improve the security of inhabitants against the expanding industrial activities. Industrial actors often opposed the creation and application of these conditions created at the end of the 19th century. The rejection of security rules from indus- trial actors was not a new thing, as an imperial decree implementing borders through distance rules between industrial sites and living areas in 1810 was similarly never applied due to the pressure of, at the time, the chemical industry (Le Roux, 2009).

This mechanism illustrates not only the difficult rise, if not absence, of borders around oil facilities in Dunkirk or their great permeability, but also the influence of industrial actors on the porosity of the port city, the application of spatial planning strategies, and thus on borders. In the example of the Clère-Boilet refinery, this influence and the reason behind the porous border and the reconstruction on the same site became evident when knowing that Mr. Clère was also the mayor of CoudekerqueBranche. His link with Mr. Trystram, who became a representative in the regional authority before being a member of the parliament and eventually senator, supports this idea of political support towards industrial activities (Denise, 1988).

\subsection{A Demonstration of Power}

The close proximity between urban areas and oil industrial sites represented the power of oil companies in port cities. It illustrated their lack of consideration for the security and health of citizens, as incidents related to oil activities demonstrated the danger of this planning practice, especially in Dunkirk. Yet, on multiple occasions, industrial and petroleum companies have used this proximity to its fullest, in Europe and beyond, until very recently.

The Cité des Ingénieurs or city of engineers in Dunkirk, designed in 1931, performed the use of both strict and permeable borders. This neighborhood, built right next to the refinery in the new port area, was influenced by the Garden City Movement advocated by Ebenezer Howard, with parks and trees surrounding the cite and isolating it from the rest of Dunkirk. After the Second World War, the renewal of the port city led to a clearer division between a port area dedicated to industrial activities and the rest of the city (Hauser \& Roche, 2020). The destroyed refining complex was rebuilt on the exact location, within the port's territory, and along with its housing district. The 23 houses right next to the refinery had an entire modern comfort with relatively large spaces and various amenities. A railway separated the industrial area as well as the refining complex from the rest of the city of Dunkirk, creating an obvious and almost impermeable border between the urban tissue and the facility, or with the port area (Figure 2). The oil companies behind the reconstruction of this site (the French branch of British Petroleum and Petrofina) created a city within the city for the facility's executives, playing with the notion of borders in the port city.

At the time of its construction, it was a desirable place to live despite the regular incidents. The hazard linked to oil activities remained, but clearer and more impermeable borders increased the porosity of 


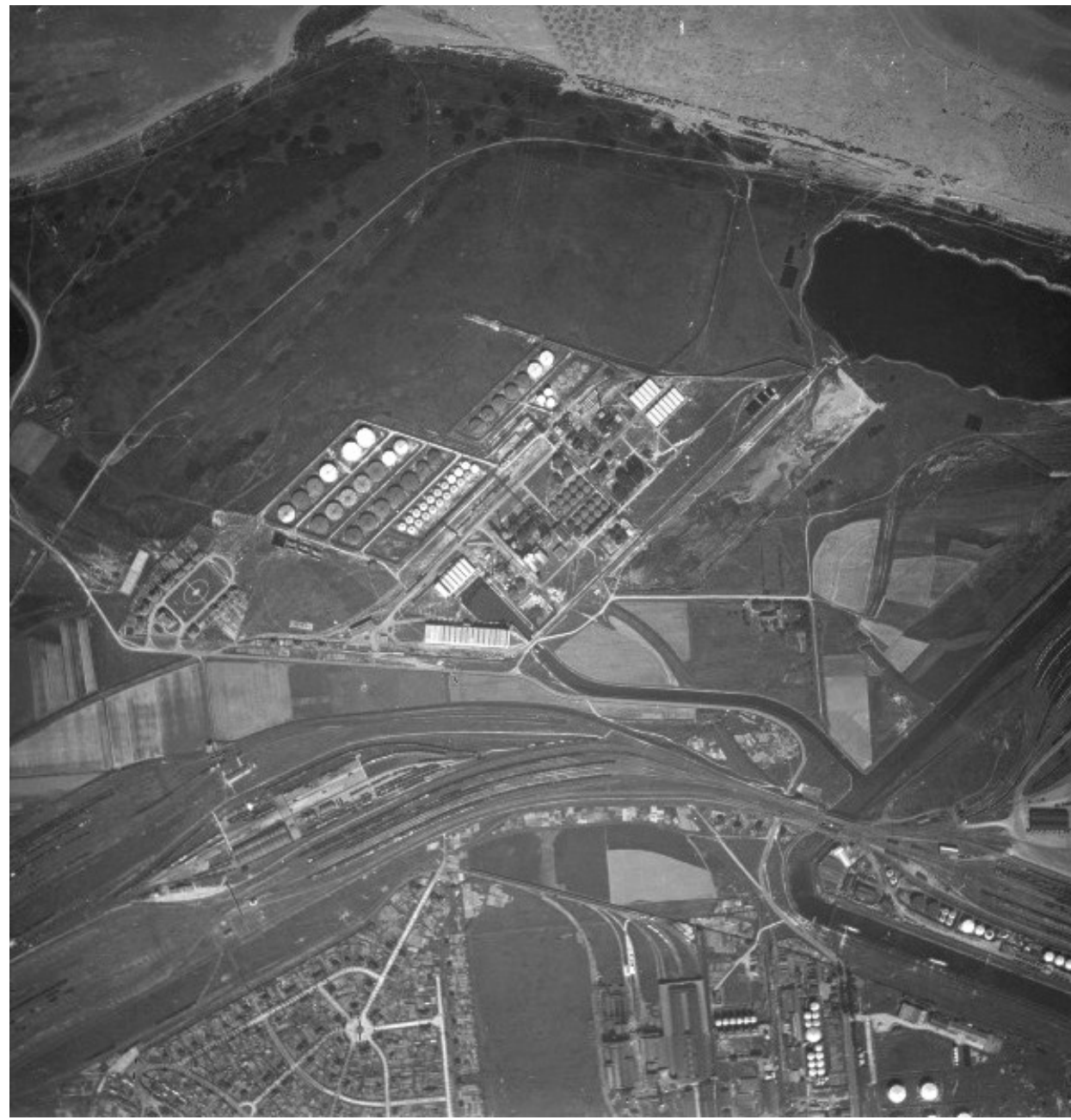

Figure 2. Aerial picture of the refinery Petrofina France, in 1936, later called refinery BP for British Petroleum, the company owning the facility. The Cité des Ingénieurs is on the southwest territory of the refining complex. Source: IGN (n.d.).

industrial port cities with the creation of spaces between port and city territories that served as buffer zones. None of the previous disasters linked to oil pushed public and private actors to prevent its construction. Similar developments happened in other parts of the world, like in Iran with the oil city of Abadan (Hein \& Sedighi, 2016). In Abadan, the oil-led developments and industrial borders went beyond the obvious spatial division to incorporate social ranks and status in the design of cities' districts. For instance, Abadan's oil refinery-located in Abadan near the coast of the Persian Gulf-was completed in 1912 and, until it was bombed and destroyed in 1980 by the Iran-Iraq war, remained one of the world's largest refineries which is part of the current Oil Museum of Abadan (Mehan \& Behzadfar, 2018). Borders were not only multiple and discriminating but also porous with the oil facility at the center of the district and the houses of the oil company's employees around it.

The multiple and regular industrial incidents, though not necessarily all connected to oil, did not immediately illustrate the importance of strict borders around industrial sites. It is only during the 1970s, together with the rise of the environmental movement, that the cité started to empty. Nonetheless, it was not due to security measures; instead, it had to do with the short distance between the noise and air pollution linked to the development of the industrial activity in the port and the housing district of the refinery (Lecuyer, 2002).

The quality of life and the economic efficiency linked to port infrastructure, more than health and environmental concerns, were the main triggers deepening the division between urban and port areas in Dunkirk. The new scale of industrial facilities, constantly bigger, became increasingly incompatible with any proximity with urban areas. The need for a great amount of space to build such facilities and the pollution (noise and air) associated with industrial activities demonstrated the incompatible proximity used in the past between port and urban areas. The border switched from an absent or permeable one, merged with the urban limits at the beginning of the oil industry, to a distinctive and impermeable one separating the port from urban areas. That is geographically and administratively only, as industrial sites and activities increased the pollution and further revealed the absence of underground, air, and water borders in the port city. This need of industries for great space and the 
important change in the scale of facilities created a norm, standard planning where port areas moved as far as possible from their cities into dedicated spaces.

\subsection{The Forced Transition of Dunkirk}

Many European port cities are now trying to deal with the legacy of oil activities and their impacts, and more significant divisions with impermeable borders are gradually being formed as a result of this trend. On the one hand, the refinery of Total in Dunkirk stopped its refining activities in 2010 and the company transformed it into a training school and an oil depot, with a new facility dedicated to the second generation of biofuels nearby. On the other hand, the former refinery of British Petroleum, called Société de la Raffinerie de Dunkerque at the time of its closure, also definitely closed in 2016. The demolition and cleaning of the latter started a few years later and are supposed to end in 2021 to host new activities. These sites being on the port's territory rather than within the urban area facilitated the already complex dismantling operations. The economic purpose of the port authority, reformed in 2008, the distance between the port and the city, as well as the gradual inclusion of local authorities and actors in the decision-making, participated in the swift transformation of the oil refinery.

With this transition, the housing district Cité des Ingénieurs together with the former British Petroleum refinery have now disappeared from the landscape of Dunkirk. The future will tell the efficiency of the new practices it applied to demolish and clean the site and to what extent the cleaning, vertically (soil and water) and horizontally (infrastructure), was carried out. In this case, as the site was located on the territory of the port and will receive new industrial activities, the soil does not need a more complete and thorough cleaning procedure than what a housing transformation would require. Yet, this process is a step forward compared to the numerous sites that settled in Dunkirk between the 1860s and the first World War and that were completely forgotten by successive authorities. The lack of early consideration for the protection of health and the environment, as well as the porous borders of the past, led urban activities to take over these former industrial sites. While never cleaned, the land use switched from industrial to housing purposes, creating a new kind of porous borders between remnants of past oil industrial activities and current housing functions (Hauser, 2020). The city's expansion slowly assimilated industrial lands, forgotten and formerly on its periphery (Figure 3).

\section{Assessment and Discussion}

With investments in other countries and an overcapacity of the refining sector in Europe (British Petroleum, 2019), European oil companies are closing sites. Dunkirk is an excellent example in this perspective because of its long oil history and the multiple permeabilities of borders that were created around its oil sites. If oil activities are slowly coming to an end in Dunkirk, the port city becomes a laboratory for an energy transition and a transformation of petroleum sites that will eventually reach many other places. Such experiments were facilitated by the distance progressively built between the port and urban areas. This distance is the tool public authorities designed to improve the security around oil and industrial sites and represents the current border between port and urban territories. The security

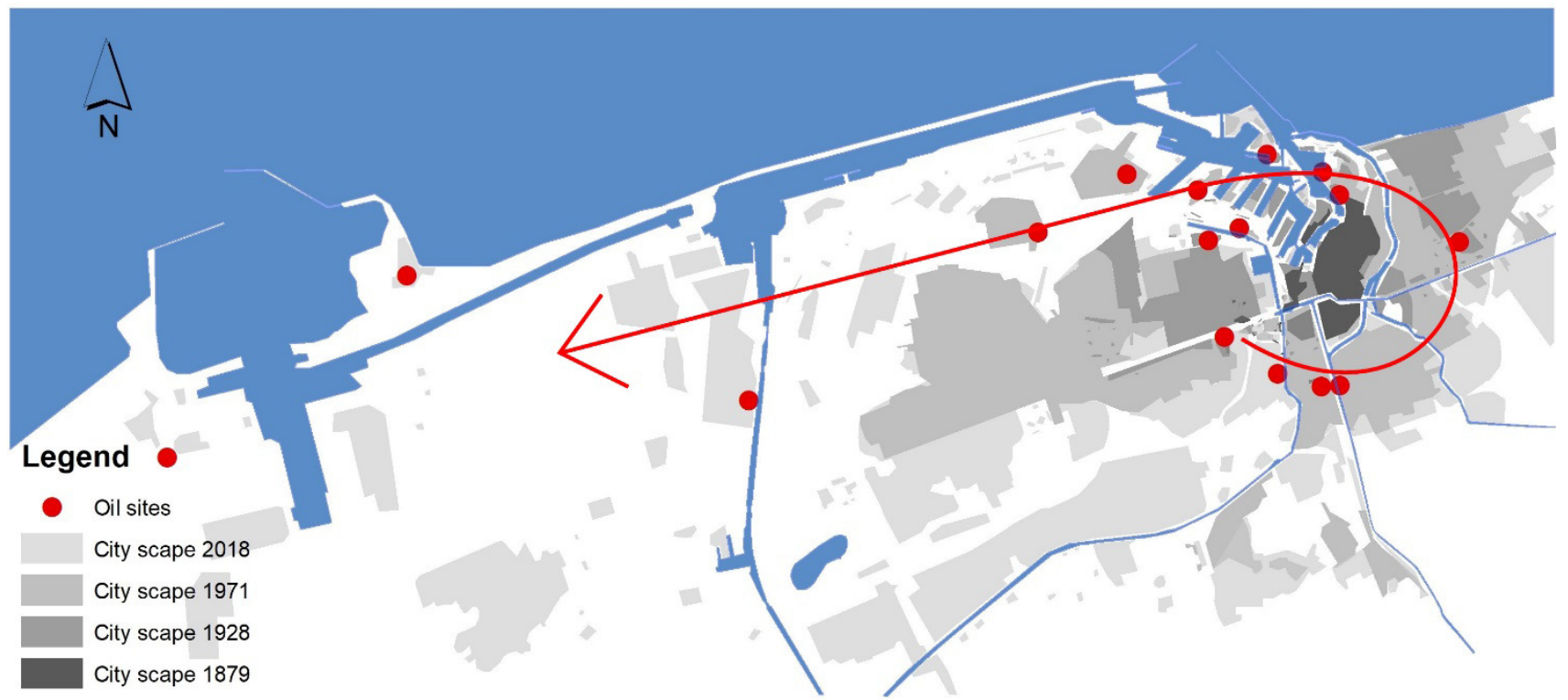

Figure 3. Map of Dunkirk showing the location of oil sites known and discovered during the research in parallel with the urban expansion of the city. The arrow illustrates the settlements through time of oil sites, from the periphery of the city towards a dedicated port area to the west. Source: Stephan Hauser using ArcGIS and archival maps of Dunkirk from Centre de la Mémoire Urbaine d’Agglomération (n.d.-a, n.d.-b). 
measures implemented after multiple incidents created an impermeable border, cutting the long ties that citizens of port cities had with industrial activities and risks.

We contend that the permeable ability of the petroleum industry to the borders determines the degree of porosity of a port city. The influence of early oil developments in port cities must, however, be investigated to create safe and coherent planning strategies for the future. Recognizing the multiplicity of actors and factors intervening in the evolution of the oil industry in Dunkirk helps understand the industry's role in the evolution of industrial port cities' porosity. Historical transformations in the permeability of borders influenced contemporary shapes and remain the ongoing challenges in the future planning and development of port cities.

Historical analyses demonstrated that public authorities of port cities ended up including former polluted industrial sites into the urban fabric. This stems from an early lack of consideration for a clear division between industrial and urban activities, which, in the current shape of the city of Dunkirk, created incompatibilities as well as problems for the health of citizens with housing areas built on top of former and polluted industrial sites. The current pledges towards carbon neutrality and renewable energies will lead to additional closures of oil sites in oil-dependent port cities. This movement must trigger anticipative strategies for managing and transforming former and current oil sites together in port cities around the world.

Regular incidents are still demonstrating the impacts that disasters in port areas can have on the life of inhabitants and cities. Thousands of people and entire cities can be affected by a lack of strict borders between the living and industrial areas. The case of Beirut in 2020 also displayed the importance of analyzing the porosity and the permeability of borders rather than implement strict administrative borders in protecting inhabitants against industrial catastrophe. The blast devastating Beirut's port and city shows the latent danger of safe storage of potentially dangerous goods in modern ports, particularly those located close to the city's heart (Mehan \& Jansen, 2020). Such a disaster in port-cities shows the interplay of spatial, social, economic, and cultural dimensions. The disconnection between the coordination and controlling of dangerous goods storage on the land side and abandonment of ship and cargo on the seaside seems to be the root cause of the tragedy in Beirut. With so many casualties among citizens, the disaster painfully shows that the proximity of a port to its city requires coordination, transparency, and community dialogue. Disasters' recurrence is a continuous warning to find an appropriate balance in the definition of borders' permeability and port cities' porosity. Unless treated seriously, efficiently, and strictly, port-cities, where most of these calamities happen, will keep on fearing this sword of Damocles. The long list of worldwide industrial incidents similar to Beirut support the need for a debate around the notion of borders in port cities and around industrial sites. These incidents highlight the past and present challenges and remaining industrial threats that authorities of port cities have to consider when planning for the future.

\section{Acknowledgments}

We gratefully acknowledge the research support and comments of members of the PortCityFutures group, especially Carola Hein and Lucija Ažman Momirski.

\section{Conflict of Interests}

The authors declare no conflict of interests.

\section{References}

Ažman Momirski, L. (2015). Urban waterfronts in Koper: A comparison of spatial issues in the initial and current plans for Koper's port. Annales-Anali za Istrske in Mediteranske Studije-Series Historia et Sociologia, 25(1), 19-32.

Brimblecombe, P. (1999). Air pollution and health history. In R. Maynard, S. Holgate, H. Koren, \& J. Samet (Eds.), Air pollution and health (pp. 5-18). Academic Press.

British Petroleum. (2019). BP statistical review of world energy [Data set]. https://www.bp.com/en/global/ corporate/energy-economics/statistical-review-ofworld-energy/oil.html

Centre de la Mémoire Urbaine d’Agglomération. (n.d.-a). Dunkerque: Ville et port [Dunkirk: City and port ; map]. Archives de Dunkerque (Cote 2Fi64). http://vdkq-portail.cloudapp.net:85/4DCGI/Web_ DFPict/034/2Fi64/ILUMP21432

Centre de la Mémoire Urbaine d’Agglomération. (n.d.-b). Dunkerque (Malo-les-Bains-Rosendaël) [Dunkirk (Malo-les-Bains-Rosendaël). Archives de Dunkerque (Cote 1Fi54). http://vdkq-portail.cloudapp.net:85/ 4DCGI/Web_DFPict/034/1Fi54/ILUMP21432

Denise, J. (1988). La belle époque à Dunkerque [The "belle époque' in Dunkirk] (Vol. 3). Editions des Beffrois.

Ducruet, C. (2007). A metageography of port-city relationships. In J. Wang, D. Olivier, T. Notteboom, \& B. Slack (Eds.), Ports, cities, and global supply chains (pp. 157-172). Routledge.

Gonjo, Y. (1972). Le “plan Freycinet," 1878-1882: Un aspect de la "grande dépression" économique en France [The "Freycinet plan," 1878-1882: An aspect of the "great economic depression" in France]. Revue historique, 248(503), 49-86.

Hall, P. V., \& Jacobs, W. (2012). Why are maritime ports (still) urban, and why should policy-makers care? Maritime Policy \& Management, 39(2), 189-206.

Hauser, S. J. (2020). Long live the heritage of petroleum: Discoveries of former oil sites in the port city of Dunkirk. Urban Science, 4(2). https://doi.org/ 10.3390/urbansci4020022 
Hauser, S. J., \& Roche, C. (2020). Sharing is caring, but is the shore cared for? The sharing paradox of the French Coast. Urban Science, 4(4). https://doi.org/ 10.3390/urbansci4040060

Hein, C. (2011). Port cities: Dynamic landscapes and global networks. Routledge.

Hein, C. (2018). Oil spaces: The global petroleumscape in the Rotterdam/The Hague area. Journal of Urban History, 44(5), 887-929.

Hein, C. M., Rutte, R. J., \& van Mil, Y. B. C. (2020). North Sea crossings: Historical geo-spatial mapping as a tool to understand the local development of port cities in a global context. In N. Couling \& C. Hein (Eds.), The urbanisation of the sea: From concepts and analysis to design (pp. 33-44). NAi Publishers

Hein, C., \& Sedighi, M. (2016). Iran's global petroleumscape: The role of oil in shaping Khuzestan and Tehran. Architectural Theory Review, 21(3), 349-374.

Hein, C., \& van de Laar, P. T. (2020). The separation of ports from cities: The case of Rotterdam. In A. Carpenter \& R. Lozano (Eds.), European port cities in transition (pp. 265-286). Springer.

Hein, C., Mager, T., \& Hauser, S. (2021). Refining the heritage narrative of post-oil landscapes. In J. Tomann (Ed.), Transcending the nostalgic: Deindustrialised landscapes across Europe. de Gruyter.

Jovchelovitch, S., Dedios Sanguineti, M. C., Nogueira, M., \& Priego-Hernández, J. (2020). Imagination and mobility in the city: Porosity of borders and human development in divided urban environments. Culture \& Psychology, 26(4), 676-696.

Le Roux, T. (2009). La mise a distance de l'insalubrité et du risque industriel en ville: Le decret de 1810 mis en perspectives (1760-1840) [The distancing of insalubrity and industrial risk in the city: The decree of 1810 put into perspective (1760-1840)]. Histoire et mesure, 24(XXIV-2), 31-70.

Le Roux, T. (2015). La "médiatisation" de l'insalubrité industrielle: Un espace public de débats progressivement étouffé, 1770-1810 [The 'media coverage' of industrial insalubrity: A progressively stifled public space for debate, 1770-1810]. Le temps des médias, 2015(2), 34-51.

Lecuyer, J. (2002, May 16). La cite des ingénieurs figée dans l'instant [The city of engineers frozen in the moment]. La Voix Du Nord.

Mehan, A., \& Behzadfar, M. (2018). The forgotten legacy: Oil heritage sites in Iran. Santiago metropolitan region. In Congreso XVII TICCIH en Santiago de Chile-Patrimonio industrial: Entendiendo el pasado, haciendo el futuro sostenible [XVII TICCIH Congress in Santiago de Chile-Industrial heritage: Understanding the past, making the future sustainable] (pp. 897-900). Universidad Central de Chile.

Mehan, A., \& Jansen, M. (2020). Beirut blast: A port city in crisis. The Port City Futures Blog. https://www. portcityfutures.nl/news/beirut-blast-a-port-city-incrisis

Monios, J., Bergqvist, R., \& Woxenius, J. (2018). Portcentric cities: The role of freight distribution in defining the port-city relationship. Journal of Transport Geography, 66, 53-64.

Mosley, S. (2014). Environmental history of air pollution and protection. In M. Agnoletti \& S. Neri Serneri (Eds.), The basic environmental history (pp. 143-169). Springer.

National institute of Geographic and Forest Information. (n.d.). 1936, photo aérienne (No. 3110) [1936, aerial photograph]. Remonter le Temps. https:// remonterletemps.ign.fr/telecharger $? x=2.325140 \&$ $y=51.029482 \& z=13 \&$ layer $=$ GEOGRAPHICALGRID SYSTEMS.MAPS.SCAN-EXPRESS.STANDARD\&demat= DEMAT.PVA\$GEOPORTAIL:DEMAT;PHOTOS\&mission Id =missions. 4972235

Sennett, R. (2010). The public realm. In G. Bridge \& S. Watson (Eds.), The black city reader (2nd ed; pp. 261-272). John Wiley \& Sons.

Sennett, R. (2015). The world wants more 'porous' cities: So why don't we build them? The Guardian. https://www.theguardian.com/cities/2015/nov/27/ delhi-electronic-market-urbanist-dream

Szeman, I. (2007). System failure: Oil, futurity, and the anticipation of disaster. South Atlantic Quarterly, 106(4), 805-823.

Tarigan, A., Samsura, D. A., Sagala, S., \& Wimbardana, R. (2017). Balikpapan: Urban planning and development in anticipation of the post-oil industry era. Cities, 60, 246-259.

\section{About the Authors}

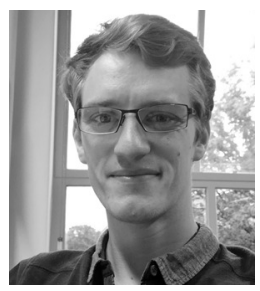

Stephan Hauser is a PhD Candidate at the Faculty of Architecture, Delft University of Technology, in History of Architecture and Urban Planning. Coming from a legal background, his research focuses on the impact of oil companies on the development of port cities and on the creation and application of regulations linked to spatial planning, and the protection of health and the environment. His publications focus mostly on the port cities of Dunkirk in France and Rotterdam in the Netherlands as two extreme examples of the oil industry's influences and evolutions. 


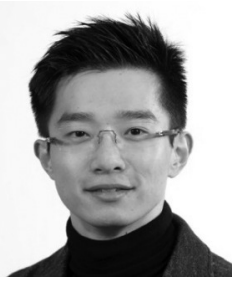

Penglin Zhu's research focuses on the emergence of port city-region governance in Dalian, which has been triggered by Chinese economic reform. The process has arguably been driven by the Chinese central government in order to coordinate the regional economic development and environmental preservation. The development of the port city-region concept-from the plan of Bohai Economic Rim to the Belt and Road Initiative-essentially reflects new features of urbanization and industrialization policies in China. The research's overarching aim is to explore the particular logics of scale production behind the institutional, conceptual, and methodological borders of the port city-region. It studies whether, how, and to what extent the state has orchestrated the mechanism of institution and administration, the preparation of spatial strategies and urban planning, and the channels of public participation to archive the regional sustainability.

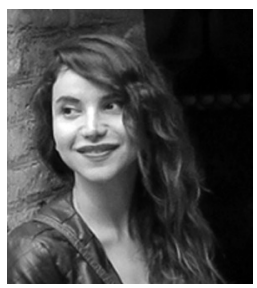

Asma Mehan (PhD) is currently a Postdoctoral Fellow affiliated both with the Leiden Institute of Cultural Anthropology and Development Sociology and the Leiden-Delft-Erasmus program for Port City Futures. Her main research and teaching interests include cultural and political geography, planning history and theory, architectural humanities, and heritage studies. Asma is the co-author of Kuala Lumpur. Community, Infrastructure and Urban Inclusivity (co-authored by Marek Kozlowski and Krzysztof Nawratek, Routledge, 2020). In terms of geographic location, she conducted research in the Middle East (Tehran, Abu Dhabi, Dubai, Istanbul), South East Asia (Kuala Lumpur), as well as Europe (Torino, Berlin, Porto) and the United States (Detroit). 